\title{
The image of a tamed landscape: dehesa through History in Spain
}

\author{
José Ramón Guzmán Álvarez \\ Consejería de Medio Ambiente y Ordenación del Territorio, Junta de Andalucía, Avenida Manuel Siurot, 50, 41071, Sevilla, España \\ e-mail: joser.guzman@juntadeandalucia.es
}

Submitted: 25 July 2015. Accepted: 16 December 2015

\begin{abstract}
This paper focus on the difficulty of applying an apparently clear and transparent concept that refers to an emblematic Mediterranean historical and cultural landscape: the dehesa agroecosystem. This agroecosystem, named montado in Portugal, is located in the southwestern area of the Iberian Peninsula. Dehesa is a very evocative word; it is a concept that, besides, shows a great capacity to contain social values and sensibilities pertaining to the modern world (respect for the environment, quality in the production processes, biodiversity, cultural heritage). Nevertheless, the concept of dehesa is situated in undefined and confusing spaces, due to the fact that its multifunctional nature involving forestry, agriculture and livestock farming prevents it from being understood by the strict dichotomous categories relating to regulatory, ecological or production aspects. In this sense, there is such disconcertion that any proposal aimed at solving the challenges of the dehesa should reach a previous consensus regarding a more adjusted definition thereof, continuing the evolution of this historical concept.
\end{abstract}

KEYWORDS: agroforestry system; ecosystem management; Mediterranean pasturelands; cultural landscapes.

Citation / Cómo citar este artículo: Guzmán Álvarez, José Ramón (2016) "The image of a tamed landscape: dehesa through History in Spain”. Culture \& History Digital Journal, 5 (1): e003. doi: http://dx.doi.org/10.3989/chdj.2016.003

RESUMEN: La imagen de un paisaje domesticado: la construcción de la dehesa a través de la historia en España.- Este trabajo presta atención a la dificultad de aplicar un concepto aparentemente claro y diáfano que hace referencia a un paisaje histórico cultural mediterráneo emblemático: el agroecosistema dehesa, que caracteriza el sector suroccidental de la Península Ibérica y es conocido en Portugal bajo el nombre de montado. La palabra dehesa posee una gran capacidad evocadora; manifiesta, además, una notable capacidad de acogida de valores y sensibilidades sociales propias de la modernidad (respeto por el medioambiente, calidad de las producciones, nicho de biodiversidad, patrimonio cultural). Sin embargo, la dehesa se sitúa frecuentemente en espacios de indefinición y confusión, víctima de algunas de sus virtudes y empantanada ante la imposibilidad de que su carácter multifuncional, forestal, agrícola y ganadero, sea adecuadamente entendido por las categorías dicotómicas de los conceptos normativos, ecológicos o productivos. En este sentido, las propuestas de solución para enfrentarse a la crisis de la dehesa deberán pasar por consolidar definiciones más ajustadas a la realidad que representan en el siglo XXI, continuando de este modo con la evolución de este concepto histórico.

PALABRAS CLAVE: sistemas agroforestales; manejo de ecosistemas; pastos mediterráneos; paisajes culturales.

Copyright: (C) 2016 CSIC. This is an open-access article distributed under the terms of the Creative Commons Attribution License (CC BY) Spain 3.0.

\section{INTRODUCTION}

The dehesa (named montado in Portugal) is a characteristic landscape of the south-western area of the Iberian Peninsula (Parsons, 1962). However, dehesa is not only a landscape, as well is an agroforestry system, a type of land use, a farming system, a ecological entity, a kind of vegetation, a pastureland, an enterprise, and a legal concept (Joffre et al., 1988; Plieninger, 2007; Moreno and Pulido, 2009; Rodríguez-Estévez et al., 2012; Huntsinger et al., 2013).

The word dehesa is a very evocative one. It is a concept that, besides, shows a great capacity to contain so- 
cial values and sensibilities pertaining to the modern world (respect for the environment, quality in the production processes, biodiversity niches, cultural heritage). All these characteristics should facilitate the forging of social commitments and alliances in order to strengthen these agrosystems against today's socioeconomic and environmental challenges, at least in comparison with other agrosystems or agricultural, livestock or forestry production systems presenting poorer collective identification.

This, however, is not so. All too often, the dehesa is situated in undefined and confusing spaces. Indeed the dehesa is a victim - to a certain degree - of its alleged virtues, thwarted by the fact that its multifunctional nature involving forestry, agriculture and livestock farming prevents it from being well accepted by the strict dichotomous categories relating to regulatory, ecological or production aspects; there is such disconcertion that the proposals aimed at solving the crisis the dehesa is undergoing involve previous consensus regarding a definition thereof. ${ }^{1}$

This is the basis of the present research: the difficulty involved in applying an apparently clear concept referring to a historical Mediterranean landscape when tack- ling the challenges that the future poses to the idea this concept attempts to represent.

In order to situate this concept in the present time, there is a need to look at its history, emphasising the evolution of a term that has embraced the changes in the relationship between humans and nature and also in our conception of resource management.

\section{DEHESA: HISTORY OF A CONCEPT}

We are barely beginning to learn of the history of this eco-cultural landscape which at present is circumscribed to the confines of south-western Europe, in the vicinity of Hercules' columns, although in ancient times it likely formed a part of the landscapes of much of the continent. Indeed, the stereotype of the pigs feeding in the dehesas and montados of the Iberian Peninsula would be familiar to the Duke of Berry, whose servants fed the herds of pigs in the oak forests in the central region of France in the XIV century, or to Ulysses himself, whom Aphrodite made dress in rags on returning from Ithaca so that he would not be recognised, and who once he reached his home, the first person he met was his loyal pig herder, who tended his herd that fed on tasty mediterranean oak acorns.

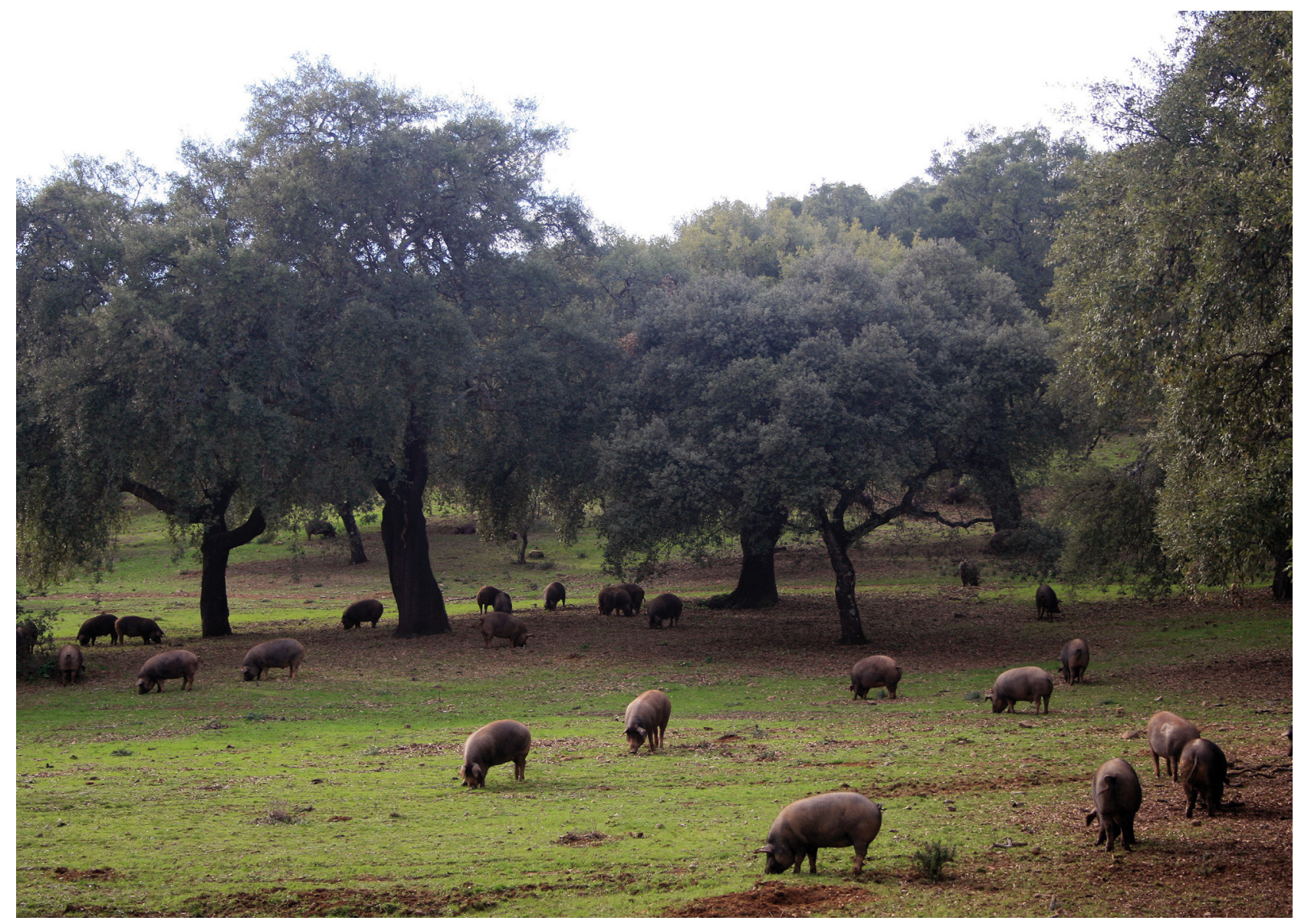

Рното 1. Herds of pigs feeding in the oak park-like forests of Spain (dehesas) or Portugal (montados). 
We lack any exact official figure of the extension of the dehesa, whatever that might be, as there is no such item in Spanish statistics. A national study carried out by the Spanish Ministry of Agriculture in 2008 gives the figure of 3515920 ha (quoted in Pulido and Picardo, 2010). Joffre and Rambal (1988) estimated that dehesa and its related montado systems cover over six million hectares in the southern Iberian Peninsula

The persistence of the dehesas throughout history and the story of the word dehesa had been studied before (Casa de Velázquez, 1986; Martín Vicente and Fernández Alés, 2006; Díaz et al., 1997; Cabo, 1998; Joffre et al., 1999; Lavado et al., 2000; Linares and Zapata, 2003; Huntsinger et al., 2013; Costa et al., 2014). Etymologically, dehesa means "defended, fenced or protected". There is some evidence which shows the use of the word dehesa since the early Middle Ages in the old Spanish code (the $7^{\text {th }}$ century Visigoth Fuero Juzgo, a law protecting fields against free grazing). Other historical sources (Corominas, 1997; Ceresuela, 1998) pointed to its first use as dating from 924.

Ecologists and foresters understand the term dehesa, and its related system montado in Portugal, as describing a park-like landscape, with a sparse tree layer composed of oak trees (usually holm oak and cork oak), located in the south-western Iberian Peninsula, that provides browsing land for cattle, grazing for sheep and goats, acorns for pigs, as well as some forest income from natural cork, mushrooms, useful plants, wood for fuel and space for bee-keeping (Díaz et al, 1997). Dehesas are typical of granite and metamorphic rocky land, where the soil is thin or absent, or consists of sand granite; trees in areas of deeper or better watered soil have been eliminated, and these areas turned into arable crops, vineyards or olive orchards. Finally, cereal crops can be yielded between the trees. In short, the dehesa is a known reference model of an agroforestry or sustainable agrosilvopastoral ecosystem in the Mediterranean basin (Dawson and Fry, 1998; Pulido et al, 2003).

This park-like dehesas had to be the result of the clearance of evergreen woodlands and their replacement by open-forest lands (Stevenson, 1985; Stevenson and Moore, 1988; Stevenson and Harrison, 1992) dating from the Neolithic period during the $4^{\text {th }}$ or $3^{\text {rd }}$ millennium BC (López Sáez et al, 2007; Stevenson and Harrison, 1992). These dehesas were likely to be created by following the known process of reclaimed land: forest clearing (with the frequent use of fire, Aschmann, 1973), control of woody vegetation, establishment and improvement of pastures. This process evolved to other methods, including the totally man-made dehesas with the improvement and reproduction of the trees planted there.

The scientific definition of the dehesa has superceded its historical meaning, reducing its initial significance of pastureland to a specific tree-layered pastureland. However, no trees or vegetation, or its geographical distribution, are included in the historical definitions of dehesa. What has happened to make its non-specific definition shift to being quite a specific one? We argue that the present concept of dehesa recorded in ecological literature comes from an academic point of view coinciding with one of the local images of dehesa for Spaniards.

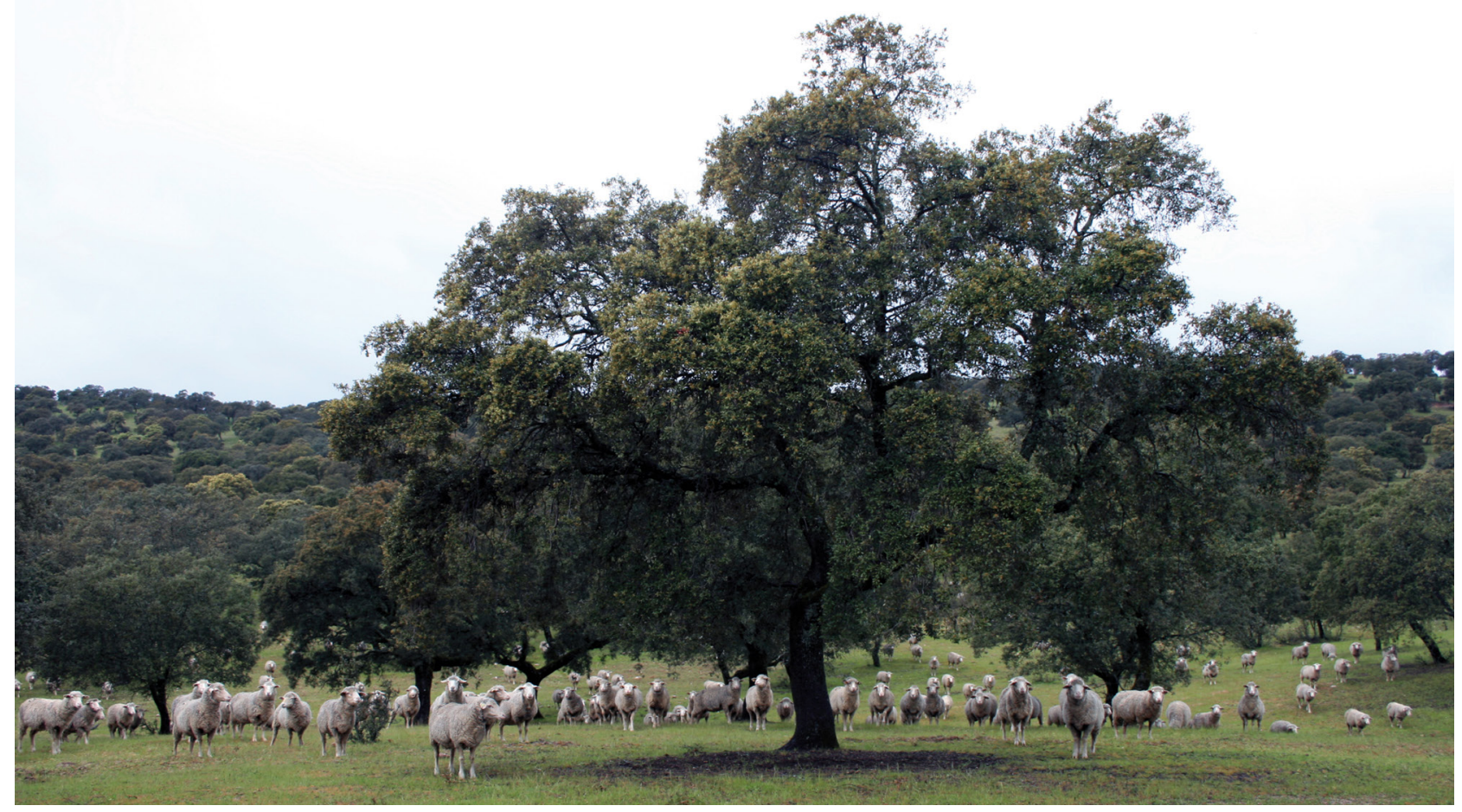

Рното 2. Local image of dehesa for Spaniards: flock of sheeps. 
In order to show the historical evolution of this concept, it is necessary to explain some major traits in the evolution of resource use, especially of pastures, in Spain. This story takes us from the early times of Castile (the ancient kingdom of central Spain) during the Reconquest up to the last century.

\section{The commons in the early times of Castile}

The frontier between Al-Andalus (the Islamic territory in the Iberian Peninsula) and the Christian kingdoms was by the course of the river Duero in the $10^{\text {th }}$ century. According to the law of the Siete partidas (codification of law under the late thirteenth century king Alphonse X), all property won from the enemy was at the disposal of the king, who could distribute it at will. As these territories were practically deserted, the Castilian monarchs initially tried to attract settlers to the newly-conquered areas by creating huge municipalities and by offering generous land concessions to their chief military, ecclesiastic supporters and Military Orders (Mangas Navas, 1982).

In a first stage, the lands conquered from the Moslems by the Castilian-Leonese kingdom were divided into small municipalities and distributed between a large number of settlers. Conversely, the extensive territory further south, between the river Duero and the river Tajo, was largely vacant for a long time, having been depopulated as a result of warfare. From the $12^{\text {th }}$ century, the Christian kingdoms moved towards the south; the territory was repopulated with a smaller number of settlers, granting the municipalities huge territories (Clemente Ramos, 2000).

The lands that had not been apportioned through royal grants remained as Crown property (crown lands or tierras realengas). These tracts were usually extensive lands of an inferior quality, often uncultivated, because the best lands were normally the first to be disposed of in royal grants. Managed lands tended to follow a ring-shape pattern, with the more intensively cultivated orchards located in the ring close to the settlements, followed by the extensive cereal fields, the grazing pasture lands and, finally, the woodlands.

The new settlers formed towns under royal (realengos) or seigniorial jurisdiction. The colonists used the lands individually as far as possible, but, often, a large land portion remained uncultivated (baldios), free for a common use. The baldios were typically woodlands (monte) of a varying density and had a variety of uses: pasture, wood, hunting, acorns and other wild fruits, and even arable agriculture. These lands were of an uneven quality, ranging from marginal areas to fertile soils and remained ownerless merely because of their low local population density or of their physical isolation (Vassberg, 1984).

The legal ownership of the baldios was problematical from the very beginning since nobody held any legal titles to them. For centuries, they were often claimed by the monarch, by the municipalities and by the nobility. Normally, it was recognized that the baldios were at the disposal of the monarch, although the use regulation of baldios was assumed to be a competence of municipali- ties. For instance, special permission for cultivation had to be obtained from the village government, whilst the residents were allowed the grazing and revenue collection (Argente del Castillo, 1991).

Apart from the lands owned by the Crown and the private properties, there were some community properties owned or used by the Castilian municipalities. These properties fell into two juridical categories: common property, set aside for the free use of the local residents (ussualy defined as comunes or commons, and, at some extend, with baldios), and propios, i.e. lands or any other kind of property owned by the municipality as a juridical entity, which were treated as private property. The propios were usually rented out by the town council, using the income to pay for public works or local taxes. Common property (comunes or baldios) was, at least theoretically, for the free use of the residents of the municipality. Nevertheless, land tenure categories in Spain constitute, in fact, a complex pattern: this difficulty in delimiting the significance of each item has led to continuous disputes throughout history. There is no chance of clearing up these concepts: comunes was a confused term that was used indiscriminately along with baldios. These categories played a significant role in the shaping of rural landscapes in Spain because of the different intensities in resource use.

\section{Dehesas and pasturelands in the Middle Ages}

Medieval Castile was the most pastoral society in Western Europe. It has been calculated that, by the fifteenth century, two-thirds of the production land in Castile was devoted to grazing (Payne, 1973). More than two million transhumant sheep and an undetermined number of sedentary livestock grazed across the Iberian Peninsula (García Sanz, 1998). The Mediterranean-type climate, however, caused dramatic limitations for livestock; pastoralists had to constantly move around in order to prevent the exhaustion of their resources. Ecology and culture combined to make migration a compulsory feature of Iberian pastoralism.

Domestic grazing regimes took on different forms, which co-existed in the same village. The first was sedentary livestock rearing; secondly, transhumance, where the flocks roamed, usually in a bi-annual régime between summer pastures in the north and winter grazing lands in the south. Accordingly, high plateaus and mountain areas were reserve zones where transhumant herds could find forage, water and shelter from the scorching Mediterranean summer. This semi-nomadic system took advantage of the mountain pasturelands, which were at their best throughout the summer. Stocks could cross almost the whole of the Iberian Peninsula by means of an elaborate network of trails called vías pecuarias, the cañada being the best known of these pathways. However, most of the flocks remained near the villages, so it was necessary to devise a system to supply them with pasture resources.

Common municipal pastures were part of the solution for the herds, especially for local livestock. Municipalities possessed a complex set of lands that were used for pasture (Vassberg, 1974). The most widespread of 
them were the ejidos and the dehesas. The ejido (derived from the Latin exitus, meaning exit) was a land area situated just outside the town reserved as pastureland for the local residents. The dehesa (from the Latin defesa, meaning fenced) was land that was fenced, at least theoretically, and usually destined for pasture. Though the term dehesa did not strictly suggest common or private property, it is probably to be originally conceived as a communal system of protection of grazing for residents, particularly for draught livestock, such as oxen. In time, a distinction was made between the $d e$ hesas dehesadas, subjected to strictly individual uses, and the dehesas concejiles, in which only certain uses, such as pastures, were privatised, the communal use of certain forestry resources being maintained, such as acorns and water (Clemente Ramos, 2005). One important feature characterizing this first dehesa is that, although a forest tree cover would frequently cover it, this was not an essential trait of its definition.

Much of the Spanish grassland was (and still is) located in woodlands, in montes. Unlike the juridical significance of the words baldios, comunes, ejidos and dehesas, monte is a forest and geographical concept, which may mean either forest woodland or a mountain. Many of the pasturelands already described - ejidos and dehesas - should have been partly or even wholly in the monte, so there is no means of properly distinguishing one category from another. The montes provided a large number of outlets: not only was there pasture grass growing between the trees, but there was also a valuable pastoral resource in the leaves and small branches of certain trees and shrubs, and the holm oak acorns were a highly prized food, particularly for swine. The practice of ramoneo, whereby herders helped their animals to graze green shrub leaves by cutting down some branches, was widespread in the montes to complement pasture resources.

From June onwards, or even before, the wild pastures became dry and of little value for grazing. In order to complement grazing resources, there was another important pasture source, which was well-suited to the complementary relationship of traditional livestock husbandry and agriculture, the custom of stubble grazing, called, in old Spanish "derrota de mieses". Derrota meant that when there were no crops growing, the fields, whether in stubble or in fallow, would be treated as common pasture. Accordingly, private rights to a field were limited to the period between planting and harvest. As the prevalent traditional farming system in Spain was not annual cropping, but biennial, triennial or usually longer fallowing rotation period systems, the total grazing-friendly area was relevant in each territory. This system led to the fresh stubble (rastrojos) and fallow (barbechos) of grain fields becoming valuable resources because this pasture contained harvest residues and spontaneous vegetation developed during the fallow period. In short, derrota, baldios and commons (such as ejidos and dehesas) encouraged almost the entire territory of a village to become a continuous commons open to the local livestock, and even to that of outsiders.
During the Reconquest, the danger of Moslem raids in some areas made livestock a better investment than easily-destroyed crops and vineyards. Hence, ranching expanded a great deal in the new frontier settlements. The creation in 1273 of the powerful Honourable Council of the Mesta, an association of sheep owners is further evidence of the early strength of the livestock industry (Klein, 1920). The wool trade was the major source of wealth for Castile during the medieval period; it also had the advantage of being easily taxable. The advent of merino sheep in the fourteenth century increased high-quality wool production and the Mesta, exporting wool to textile factories in northern Europe, carried on a huge trade. The Mesta flocks could have grazed throughout Castile, only keeping them away from five preserved lands: cropping fields, vineyards, orchards, meadows, ejidos and dehesas boyales. Baldios were open to the Mesta flocks in accordance with the earlier royal regulations, but as the term was ambiguous, some towns were able to assert their authority over these tracts, defending their use as commons.

The Crown was concerned about the necessity of fencing pastures: Alfonso X (1252-1284), at the peak of the Reconquest, allowed the use of three aranzadas of land per pair of oxen (roughly $1.8 \mathrm{ha}$ ) from the tierras realengas, as dehesas in each municipality. The population growth, the spread of arable land and local conflicts led to a proliferation of dehesas, which were established by the Crown via local government. This Crown protection was essential for municipalities and private properties, because grazing by transhumance herds was forbidden (Linares Luján et al., 2003). However, the wool trade grew and became of outstanding importance to the royal economy, and the size of herds increased exercising their pressure upon the baldios and putting a stop to fences.

There were different categories of dehesa. In the Medieval and Modern ages, every Castilian municipality had at least one common dehesa; in that case, those pastures were created for draught oxen, dehesa boyal, a fenced pasture reserved for plough oxen, which were the most frequent draught animals before the sixteenth century. When mules gradually replaced oxen as the most prevalent ploughing animal, they were allowed to share the use of the dehesa boyal (Vassberg, 1974). The dehesa boyal would usually be located near the village, in a site where there was pasture, shade and water. As a rule, this pastureland was reserved for the exclusive use of local animals; its integrity was frequently under menace, to the extreme that a law was issued in 1438 to prevent illegal livestock being taken into the dehesa boyal. Municipalities could own other dehesas that were not specifically boyales (Salomon, 1964). Some of these were open to all animals without any discrimination, while others were reserved for the exclusive use of certain types of animals (for instance, dehesa yegual o caballar, for mares and their young, and dehesa carnicera, reserved for butchers' herds in order to provide better, cheaper meat).

In the period between the XV century and the end of the XVI century in the municipalities in western Spain, one 
could distinguish between an initial circle that included closed spaces and common lands/ejidos, a second sector of cereal crops, vines and collective spaces, and a third one for extensive livestock farming, with dehesas, marginal agricultural spaces and monte. The first circle contained the ejidos (land demarcated for use by communal livestock, intended for self-supply of residents or for use by the village as a whole, except for oxen, which had their own space) and fields for vegetable gardens and vineyards, which took the shape of a multicrop system with dispersed trees that gradually took over the land of the ejidos. The second circle included open fields, cereal croplands and vineyards without trees, together with the common lands: dehesas boyales (for beasts of burden oxen and asses), dehesa caballar (for military use, found in villas and cities for use by the oligarchy) and different kinds of cotos or dehesas de la carnicería, spaces intended for animals for consumption. Cereals were grown following a rotation system of año $y$ vez (two-yearly) that allowed communal use of stubble and integration of agricultural and livestock farming uses. In the third circle there was a predominance of the livestock farming and forestry uses including other dehesas: delimited private lands mainly used for rent of pastures for large herds of livestock, whether or not in transhumance.

The size, location, and local use of the dehesas differed in terms of their geographical and historical factors. It was probably desirable to have trees in the pastures because they provided protection from sun, wind and rain, and branches could be used as emergency forage during drought periods, but this was not a sine qua non feature of the character of dehesas.

Acorns constituted one of the major benefits of the dehesas, in the frequent cases that contained oak-trees. Acorns were not only used as food for animals, but in famine years they were also consumed by humans as acorn-bread. Not all montes and dehesas had oak trees, certainly, but those that were rich in these trees were prized for their acorns because a flourishing swine livestock could be maintained (Parsons, 1962). City and town councils usually supervised and regulated acorn harvests to guarantee maximum profits.

The dehesa was, therefore, in early times not strictly a pasture land with dispersed oaks. In fact, there was an old Spanish term for this, monte hueco (which could be translated as "hollow forest"), defined as land in which there were sparse oaks and other trees and from which, when looking down through their canopy, one could freely see to some considerable distance below (Grove and Rackham, 2001).

\section{The dehesas during the Spanish Empire}

The Spanish forest surface lessened continuously after the Middle Ages (Bauer, 1991). The need for more agricultural land increased deforestation, accelerating the loss of woodland. Deforestation was also carried out for construction, firewood and, notably, for shipbuilding. The woodlands suffered as well during the wars since they could cover up enemy movements. As has been argued, the rise of the Spanish Empire took place against the background of an intensive environmental change (Braudel, 1975; Simmons, 1989).

The monarchs of Castile increased the Mesta privileges. A 1501 law (Edicto de Posesión) declared that all lands upon which the transhumant flocks had ever grazed were to be reserved in perpetuity for pastures and could never be used for any other purpose. In 1528, a royal regulation stipulated that local governments could not deny their commons to the Mesta flocks unless the Crown had reserved the land (Sánchez Salazar, 1988). Only in the late $15^{\text {th }}$ century the Crown stopped favouring the organization and start to take into account the increasing anti Mesta movement. Its grazing rights were reduced, as a consequence of a change in Castilian economy.

The Mesta and the local peasants had an antagonistic relationship. Initially, this was not probably a typical arable-pastoral conflict, but a fight for the use of the same pasture resources between transhumant and sedentary livestock. The local municipalities and peasants wanted to defend their pastures for their own use and the protection of the baldios under the legal concept of dehesa was a reliable method to obtain this. Later, with the expansion of cereals, vineyards and olive crops in the sixteenth century, the farmers put some pressure on traditional pastureland by invading transhumance lands such as baldios, cañadas or dehesas. Any new cultivation in the baldios generated legal battles between the Mesta and the farmers, a struggle that was reflected in the fluctuating laws during the sixteenth and seventeenth centuries (Lynch, 1964).

Spains's population growth resulted in increasing amounts of land being cultivated in the sixteenth century. This increasing demand was accompanied by an expansion of the food supply obtained through agricultural production by enlarging areas under cultivation rather than by raising agricultural productivity through intensive cultivation or through a qualitative transformation of the existing agrarian production forces, so that the agropastoral balance shifted in favour of cultivation. Montes areas underwent increasing damage caused by peasants, stockmen and city dwellers in search of fuel and timber. This tendency - expansion of arable lands to increase production at the expense of the pastoral sector- was the general trend during the next centuries, except in periods of population decline, such as in the sixteenth century.

An important technical innovation led to agrarian expansion: the gradual substitution of oxen for mules as the predominant draught animal. A mule could plough nearly twice as much land as an ox and this animal was more suitable in vineyards and orchards. However, mules usually ploughed shallower furrows and they needed a large amount of grain, which meant that a significant proportion of the land had to be oriented towards mule feed, whereas oxen could sustain themselves exclusively on the dehesas and other common pastures that were readily available. Also, to breed mules it was necessary to reserve pastures for horses, donkeys and mules were unproduc- 
tive as meat for human consumption. As a consequence, mule husbandry required more monte and pastureland to be broken up to bring it under cultivation. Therefore, the use of mules probably unwittingly helped towards the rise in clearings and the conversion of grasslands and dehesas into arable lands.

In order to understand landscape transformation and land use change during the $16^{\text {th }}$ and $17^{\text {th }}$ centuries, it is necessary to emphasize one major economic factor. The royal economy was bankrupt so that the Crown and the municipalities had to devise alternatives to increase their incomes. One of them, with little success, was to sell enclosure privileges by denying access to the lands to any animals except those belonging to private owners. These newly-fenced areas were called a number of different names: cotos redondos, términos redondos, cerramientos, and also dehesa. However, soon after, the fencing system produced a strong resistance, and, in 1566, Philip II promised not to create any more enclosures (Vassberg, 1975).

Additionally, common rights were suffering aggressive attacks from usurpers. Individual landowners - not only nobles, but also peasants and ecclesiastics desirous of establishing full property rights - arrogated to themselves the right to declare their lands as being fenced and not subject to common rights such as the derrota de mieses. The baldios were also appropriated by land users without any legal grounds for doing so.

Another element involved in the reduction in communal surface was the sale of baldios. The Crown, from the last decades of the fifteenth century, had exploited this huge heritage. The baldios had been initially sold, frequently to smallholders, to legalize lands that had been illegally ploughed, but, after a few years, the policymakers of the Royal treasury decided to adopt a more marketoriented attitude in an effort to increase its income (Calvo Poyato, 1990). Municipal lands were also sold by rural townships to buy up their obligations to their lords and to pay the increasing taxes required from the Crown.

Both the sale of baldios and the enclosure movement (either by usurpation or authorized by municipalities and the Crown) reflected the expansion of individual ownership at the expense of the commons. These processes of selling the common heritage also led to an increase in the number and surface of large estates. Many dehesas had to be especially affected by this cultivation wave.

At that time, the dehesa still conserved its characteristic of being, in an ecological sense, exclusively pasture land, independently of its vegetation, which would be tree forested - in a more or less sparse fashion-, but also a shrubby or a completely afforested field.

\section{Enlightenment and alienation}

In Spain, the sixteenth century was characterized by a decline in population due to the joint action of disease epidemics, war consequences and socio-economic factors (Domínguez Ortiz, 1963). Agriculture decreased steadily, not only affected by the population crisis, but also be- cause of the enormous impact of taxation on peasant agriculture, and the inflation rates. The result was a dramatic rural depopulation in large areas. A spontaneous recovery of forests occurred; it lasted until a demographic rise took place in the late seventeenth century, accompanied by a renewed clearing and cultivation of abandoned lands. From then on, the population steadily rose.

In the eighteenth century, agricultural production was stimulated by population growth, regulation changes and the rise in food prices, encouraging the growing of mainly grain crops, but also vineyards (Domínguez Ortiz, 1976; Herr, 1989). Sedentary livestock husbandry became comparatively more important than migrants; by the second half of the seventeenth century, the sedentary flocks numbered some nineteen million heads, whilst transhumance herds reached their peak, some three and a half million (Anes, 1994), despite the decline of the Mesta, which was finally abolished in 1836 . At the same time, other regulations encouraged peasants to bring land under cultivation; as a consequence, many dehesas were more used as purely agricultural lands (Linares Luján and Zapata Blanco, 2003)

The mid-eighteenth-century Catastro of Ensenada, which was the first comprehensive statistical survey of the nation's resources, drawn up between 1750 and 1760, showed that towns and cities possessed some dehesa boyal or dehesa del común (common dehesa), but also a number of private dehesas or montes adehesados. The rights affecting these private dehesas used to be complex because the ownership of the land and of the trees was very often different. For instance, in the city of Baza, in south-eastern Spain (not in the currently defined ecological dehesa area, but in a more semiarid location), there were three dehesas: the first was a privately-owned dehesa de pasto (a grazing deforested one); the other two were dehesas de monte (meaning afforested), with the acorns belonging to two separate owners and the pasture was common property of the local community (Cano García, 1990). Another example is the case of Hinojosa del Duque, a town situated precisely in the present dehesa area in Sierra Morena (south-western Spain). The survey records a large number of dehesas: the town possesses as propios one dehesa boyal, two dehesas with grass and acorns and another with grass, acorn and arable land; there was also one baldio covered by pasture, shrub land, oak woodland and arable land with the grass being the common property of the local inhabitants. The Duque of Béjar, a private landowner, had three dehesas with grass and acorn, and, finally, there were a number of quintos adehesados, a portion of land with a scattered layer of oaks (Torres Márquez, 1994); in short, a complex panorama that prevents us from coming to any sound conclusions.

According to the Dictionary of Authors of 1726, Diccionario de autoridades, at that time a dehesa was still a non-arable land oriented towards grazing. Although at this time a campaign against the commons had started, the enlightened reformists recognized the importance of reserved grazing areas. One of the most relevant politi- 
cians, Pablo de Olavide, although complaining in his official reports in 1768 of the large amount of vacant land in Spain due to extensive grazing, when promoting new settlements in deserted areas of Sierra Morena, in the south, established the reservation of a piece of land as a dehesa boyal for the common grazing of local draught animals (Perdices Blas, 1993).

The Enlightenment age meant, actually, the definitive expansion of cultivated lands. Almost the only way of increasing production was to place under cultivation the under-managed lands, especially pasture and forest land of comunes and propios. Some reforms affecting the distribution of commons and of church lands were formulated during the last decades of the eighteenth century in the context of a turbulent period, marked by European wars and invasion by Napoleonic troops. The impact upon the forest and pasturelands was dramatic: thousands of hectares of montes, baldios and propios were broken up and brought into cultivation.

Although the sale of church lands had begun at the end of the seventeenth century, the definitive attack against the communitarian use of land and the conservation of baldios and uncultivated land took place in the following century in the alienation period, based on the sale of public and church properties. The properties of the aristocracy were not affected, although the abolition of old rules such as seigniorial jurisdiction and the mayorazgo (whereby the properties could not be divided up) led to a great deal of land being placed on the market. Subsequently, as from the early years of the century, the municipal properties (propios) and other commons were forced to be distributed and sold. The purchasers were mainly middle class and wealthy landowners; in order to clear the forests for them to be turned into pasture lands, the new land-owners rented small pieces of land to peasants, who cleared the trees with the right to sow cereals during a number of years. This state-directed alienation process (desamortización) dramatically affected the communitarian land use system of many municipalities, involving a drastic rise in pasture and forest reclamation (Costa, 1898) (although to reduce the effects of this regulation on rural economy sparing the dehesas boyales from the sale was attempted).

The conversion of bush and forest ecosystems into cultivated land reached its maximum rate during the second half of the $19^{\text {th }}$ century. The intervention of the recently created Official Forestry Department played an important role in conserving part of this heritage, although millions of hectares of pasture and woodlands were cleared and turned into arable fields (Bauer, 1991).

Spanish agriculture underwent considerable changes when the common fields were fenced into holdings belonging to private owners, because the land started to be used more intensively (Kondo, 1990). Between 1800 and 1860 , the area under cultivation in Spain increased greatly, from 8500000 to 13000000 ha (del Moral, 1979). In spite of this general review, it is difficult to draw any firm conclusions about the desamortización: in some places the result was an enlargement of the estates owned by the bourgeoisie, whereas in others there was a certain degree of fragmentation and distribution of land.

The lack of improvements in farming techniques prevented any increase in the productivity of grain per hectare. After some decades of expansion, in 1860 a period of crisis began which particularly affected wheat production. The marginal lands pressed into tillage during the earlier part of the century were relatively unproductive, and their yield could not compete with cheap foreign imports after 1882, so that these marginal lands were to be abandoned. Conversely, there was a great expansion of vineyards and olive groves during the second half of the nineteenth century because of a rise in exports (Zambrana, 1987; Guzmán Álvarez, 2004). From 1880 onwards, the vines suffered from phylloxera, with thousands of hectares all over Spain being abandoned. Some of these changes meant an intensification of land use and, therefore, many dehesas vanished, pushed out by the cultivated crops. But a great deal of these cultivated lands (it was previously either pasture land or woodland) was turned into monte a few decades later, when the crops and vines were in crisis; subsenquently, landowners, using labour, pruned and formed oak seedlings into a sparse framework of promising trees. Consequently, many of the present day dehesas (characterized by an even-aged tree layer) come from the period from 1870-1920, in that renewal and creation phase of new dehesas (we should point that the first certain use of the modern term dehesa for a savannah-like landscape was coined at this time, by the French writer De Lawrence in 1889 in Extremadura, Grove and Rackham, 2001).

To sum up, there was not a single result of the desamortización process in the nowdays defined as dehesa area, because, depending on the practices of the new owners, the dehesas were intensified and even replaced by arable lands, or could have been conserved through fencing and the prohibition of common use (Hernández, 1995). One important factor determined the future of most of these territories: the soil fertility was insufficient for maintaining a cereal or olive yield for very long, so that clearing a whole field of trees was not considered to be a good alternative. ${ }^{2}$

\section{THE DEHESAS IN THE $20^{\text {TH }}$ CENTURY}

Economic development has characterized twentieth century Spain (Simpson, 1996). In the 1960s and early 1970s, Spain was in the process of its transformation from an underdeveloped to a developed country. Between 1950 and 1980, agricultural production doubled and the traditional methods were replaced by highly technological ones (Naredo, 1996; Campos, 1983). As a result, the rural landscape changed in extensive areas of Spain following the general trend of an intensification in the most fertile soils and the abandonment of the less fertile areas (Naredo and Campos, 1980; Fernández Alés et al., 1992).

The dehesas and the montes were not turned into arable lands when the soil was deficient, the slope was excessively high or when the specific socio-economic con- 
ditions did not promote crop conversion. Many dehesas located in better conditions were broken up to cultivate cereals; if forested, their trees would be removed. Some years later, if cultivation was not profitable, the land could be shifted to pasture land or be abandoned when grazing was reduced. Hence, a piece of land could be affected by one or more of these destruction and restoration cycles.

The extinction of common rights and the consolidation of private ownership meant an important change in the significance of the dehesa concept. In many towns in Spain there are no longer any commons rights upon the land. However, the word dehesa still persists in the vocabulary and maps. Some of these map-dehesas are forested, most of them with oak trees, but there are also some completely deforested, in spite of being grazed. There are even some completely cultivated map-dehesas in an arable area context, far away from any trees.

Starting from the mid-twentieth century, and in some spheres of activity, the significance of the dehesa concept began to be restricted to a specific park-like pastureland, covered with a sparse oak tree layer. In fact, for a long time, this dehesa had been the dehesa par excellence for some people, especially in south-western Spain, just because it was the dominant landscape. Social factors such as land tenure and the forest regulations and ecological constraints from the extension of arable cultivation have led to tree conservation.

These properties in the west and southwest of Spain, located on the acid soils derived from the Palaeozoic rocks, were mainly devoted to extensive livestock raising (sheep, pig, cattle and goat) in a pattern described by different authors (Campos, 1984; Joffre and Rambal, 1988; Plieninger et al., 2001, 2003, 2004; Moreno and Pulido, 2009; Standiford et al, 2013). The clearing of woods to open up the canopy, in order to promote pastures, produced parkland like-dehesas. Forests were also cleared to exploit the charcoal, as they have been for centuries. In some areas, deforested tracts were replanted, creating newly forested dehesas, improving the trees through selection for the production of sweet holm oak acorns or, in other areas, planting cork oaks for cork production. The result of these processes is that it is difficult to establish exactly if the present day dehesas surface came from the clearance of the natural oak forest, from the regrowth and clearance of secondary holm oak shrub lands, grazed and cultivated for centuries, or from the planting of acorns. Oppositely, many dehesas had definitively lost their tree layer (perhaps centuries ago) and the trees have never been recovered. Or, in other areas, dehesas are still a tree cover landscape, but with the presence of other tree species such as holm oak (Quercus robur, Quercus petraea), wild olive tree (Olea europaea), carob tree (Ceratonia siliqua), ash (Fraxinius excelsior) or junipers (Juniperus spp.).

The last two centuries - with the exception of the post civil war decades with their self-maintenance regime - have seen a considerable shift away from the self- sufficiency land use system. In Spain, industrial influence was relatively small until the 1970s. Iron ploughing machinery, chemical fertilizers and biocides all came in at various stages after the late nineteenth century. Major changes in the ecology of pastoralism also came with industrialization. In some areas, the transition from a traditional land use system to an industrial one happened quite late, and, moreover, the intensification process had not been a great success (Naredo, 1996). This is the case of the low-input livestock husbandry system in the southwest of the Iberian Peninsula, based on the exploitation of the local dehesas (Vacher et al., 1985).

\section{The park-like dehesa}

As we have argued, the dehesa as a concept has changed throughout history. From its early times, dehesa meant a reserved land pasture often oriented towards local livestock grazing. Afterwards, as the importance of common rights declined and private ownership expanded, the significance of the term dehesa broadened and came to mean "a fenced land pasture". This was still linked to the idea of reserved land not for free use; the difference was that private landholders took advantage of official sales and usurpations to configure their own dehesas by clearing the forests to convert them into grazing land.

In 1900, a dehesa was still described as a "monte de pasto, esté o no esté acotado" (Jordana and Morera, 1900). As we have explained, in Spanish the word monte means both "mountain" and "forest", so this definition could be translated "as a forested pasture land, either fenced or not". There is no vegetation in the definition, although in many regions there is an identification between the words ahuecar (to clear a woodland, conserving a dispersed tree layer) and adehesar (to make dehesa).

Nowadays, dehesa still means a pastureland, which is usually fenced, as it appears in the Official Spanish Dictionary (Dictionary of the Royal Spanish Academy of Language, 2014). No trees are involved in this definition: the dehesa is not (yet) a botanical or an ecological concept. For many people living in rural areas, a dehesa is simply a pastureland (or, oftenly, it was a pastureland because it has been modified), and even in many cases a dehesa is just a place name on a map, in a plot which is presently cultivated or urbanised.

The difficulty in defining dehesa lies in the fact that it is a social, cultural and historical category. It's a multimeaning word (Lavado Contador et al., 2000) which specific definition depends on the approach being adopted. There are several dehesas: the shepherd's dehesa and the ecologist's dehesa, the dehesa of a farmer and the dehesa of a bird-watching tourist. There are forested and deforested ones, although, originally, the majority of dehesas probably had to be forested. Dehesas can contain different species of trees. It's an agroecosystem, a pastureland, a landscape or a land use model. But for scholars and for administrative purposes, dehesa should be a concrete concept, should it not? The practice of science and the ap- 
plication of laws requires definition; however, working with words has to deal with the fact that vocabulary sometimes has a slippery role to play (Huntsinger et al., 2013).

Assuming that we need some clarity, let us be enlightened by our judges and lawyers, who need really precise concepts about which to argue. In the last decades there have been a number of definitions of dehesa in public regulations, each for a particular purpose. For instance, Law 1/1986 brought in by Extremadura (a region in the southwest of Spain), defines dehesa as a low-input pastureland of over 100 ha. The application of the agri-environmental scheme of the EU policy in Andalusia, in the south of Spain, defined it as an agrosilvopastoral system, usually derived from the clearing of a Mediterranean woodland, with a mainly purpose of stock-raising (Order of 6 April, 1999, Andalusian Regional Ministry of Agriculture).

A sound place to find a practical definition of dehesa may be scientific publications. The ecological concept of dehesa identifies it as an agroforestry system located in the south-western Iberian Peninsula characterised by the presence of a savannah-like open tree layer, mainly dominated by Mediterranean evergreen oaks (holm oak or Quercus ilex and cork oak or Q. suber) and, to a lesser extent, by the deciduous $Q$. pyrenaica and $Q$, faginea (Joffre and Rambal, 1993; San Miguel, 1994; Moreno and Pulido, 2009). It is characterised by a semi-arid Mediterranean climate, with annual rainfall ranging between 400 and $700 \mathrm{~mm}$, dry, hot summers and cold, wet winters with a great variability between years. The soil usually consists of a thin, stony layer on top of the deep rock (schist and igneous rocks), which is easily erodible and poor in nutrients.

From this point of view, dehesa is characterised by: a) a particular physiognomy (a savannah-like or open park-like; b) a type of land use based on extensive (and game) livestock production; c) a basically two layered structure - trees and grass - ; d) a particular geographical distribution. This dehesa narrowly coincides with the representation of the dehesa for the rural population of southwestern Spain because its pastureland can be described as a savannah-like landscape with an oak tree layer.

The change in its meaning has been favoured by the identification of the dehesa as a potentially well-adapted and economically viable multi-use agro-ecosystem suitable for promoting sustainable development in many farming areas of the Mediterranean basin. Therefore one of its historical meanings has gained a public relevance, mostly in academic and scientific works (Scarascia-Mugnozza et al., 2000). For urban inhabitants, this dehesa has come to be the dehesa par excellence. Its balanced, park-like physiognomy might have contributed to this, fitting in perfectly with our widest aesthetic tastes. It would seem that an ecosystem in which grass, bush and tree species coexist and contribute to the feeding of livestock (sheep, cattle, pigs, goats and equines) and wildlife (including game species), and to the preservation of the environment in an extensive regime is not merely a sort of ecologist's paradise but also the image of paradise for a great many humans.

A major key of this agroecosystem lies in its enclosed nutrient cycle. Compared to standardized Mediterranean agriculture, the flows of energy through the dehesa ecosystem are low, since dehesa outlets generally deflect only a minor part of the fluxes of the ecosystem towards themselves, whereas cropping systems change whole parts into crops (Naredo and Campos, 1980). Fertilizer and other energy surpluses are usually quite low. However, it should be realized that outputs are also scant.

The dehesa's tree layer modifies environmental characteristics the same as in other savannah ecosystems (Scholes and Archer, 1997). The vegetation structure is made up of two main ecological components. The first is located outside the tree canopy and is composed of herbaceous plants; the second is composed of the oak tree and its associated herbaceous stratum. Tree canopy promotes a mosaic-like structure of herbaceous plant assemblages due to the shift in environmental conditions when comparing the situation under the tree and between trees (Puerto and Rico, 1988). Grass and crops take advantage of the shade provided during the hot periods; under the tree cover there is greater moisture and more organic elements in the soil from leaf shedding and animal excretion (Cerdá et al., 1988; Joffre and Rambal, 1993). As a result, there is twice as much potassium, phosphorus, nitrogen and carbon as in soils in the same field not under the trees, so that some ecological attributes like diversity and productivity tend to increase (Marañón, 1986).

The pastures are characterized by their low production. There is a production peak during the autumn and spring, accompanied by a sharp decline in summer and winter; during these periods, livestock has to be maintained with forage. Cereal crops are still produced in $d e-$ hesas with suitable soil conditions; however, this is not a generalized practise. When grown, the cereals are usually grazed by the stock or harvested for animal feed during the drought period.

Canopy density is maintained at 10-60 trees ha ${ }^{-1}$, with the optimum ranging between 50-60 trees $\mathrm{ha}^{-1}$. Holm oaks (Quercus ilex) have various values as fodder crop, providing acorns and leafly branches, whilst cork oak (Quercus suber) main resource is cork. Mature trees are pruned regularly during the life of the oaks to remove selected branches, broaden their canopy cover and increase acorn production. Other wood products such as timber, charcoal and tannin used to be collected, although, at present, forest pursuits have been almost only reduced to natural cork.

A variety of grazing animals are reared in the dehesas, including sheep, goats, cattle, bulls, pigs and deers. Swine production is of special interest, because a particular breed of semi-feral pigs grazes acorns (Rodríguez-Estévez et al., 2012). Grazing exerts a powerful effect upon the flora and the system's sustainability de- 
pends on carefully controlling it. When overgrazed or subgrazed, an inexorable shift towards inedible plants is likely to happen.

In the park-like dehesas are a number of endangered species such as Spanish lynx (Lynx pardina), black vulture (Aegypius monachus) and Spanish imperial eagle (Aquila adalberti), and several breeds of cattle, sheep, goats and pigs threatened with extinction have been conserved.

It has been pointed out that the dehesa shows a remarkable stability, biodiversity and sustained productivity (Bignal and Mc Cracken, 1996) as a result of its balanced two-tiered vegetation structure, incorporation of animal husbandry and botanically rich mosaic-like herbaceous plant layers. However, it has to be stressed that dehesa only maintains its equilibrium with sound human managing, keeping the woody and bushy vegetation under control, and relegating the shrubs to restricted areas.

In fact, when aplying this modern dehesa concept, centred on an ecological and landscape approach, there is the risk of forgetting that its conservation depends on a particular land use management and that its peculiar physiognomy is due to a specific ecological key factor: its extensive stock-raising use. We should remember that, whatever it is, it is not a natural ecosystem but rath- er an anthropogenic agro-ecosystem, a cultural manmade landscape (Silva Pérez, 2010). Therefore, the dehesa is in need of human actions in order to guarantee its continuation.

\section{THE NEED OF A NEW APPROACH FOR DEFINING THE DEHESA}

In the 1960s, the dehesas were still exploited in the traditional manner that was quite similar to the farming practices used one century ago (Acosta Naranjo, 2002). Invasion of their grazing layer by thicket, for instance, was controlled by manual uprooting and mule ploughing; in some cases, expert farmers still selected the most suitable acorns from the sweetest trees to regenerate the tree-layer (González Bernáldez, 1991). Afterwards, the dehesa agro ecosystem has suffered from severe problems (Campos, 1983; Campos et al., 2003; Vacher, 1984; Huntsinger et al., 2013; Costa et al., 2014): abandonment and thicket expansion due to the decrease in agro-pastoral management practices; the lack of tree layer regeneration; local overgrazing and ill-management of the system; an increase in deforestation and clearing processes to extend cropping lands in more fertile areas; and, lastly, tree decline commonly named as seca.

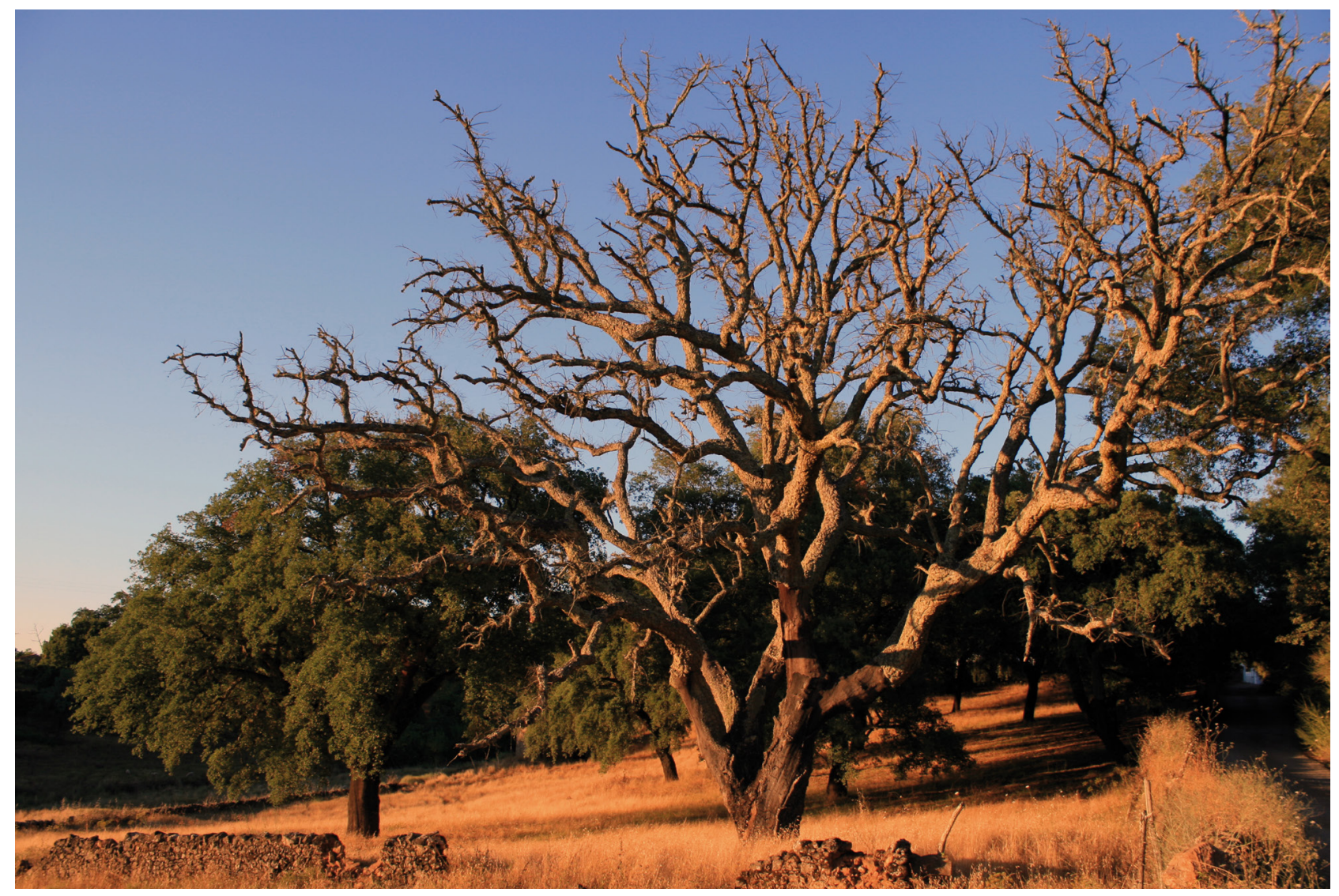

Рното 3. The lack of tree regeneration is one of the most severe problems of the dehesa agro ecosystem. 
Dehesa abandonment during the 1970s and 1980s had a lot to do with the system's inability to adapt to the new socio-economic conditions derived from the economic growth of Spain. During that same period, deforestation in order to extend mechanized cropping was a threat to the dehesas in some areas in the context of Spain's economic growth.

From the 1990s onwards there has been a recovery of the dehesa as a farming-system. The increasing quality awareness of the consumers and the environmental consciousness of modern societies brought about the revaluation of the dehesa as a model of sustainability. Extraquality hams and meat from the feral pig have become a reference in Spanish food, causing stock numbers to rise.

During the last decades, a number of influential changes have taken place, triggered by economic growth and the emigration of the rural population (Plieninger and Wilbrand, 2001). Dehesa pastoralism has practically disappeared in the form known to us. At the farm level, sheep have oftenly been substituted for cattle and game-hunting species (Joffre et al., 1988); these animals are more suitable for modern dehesas than the traditional flocks, because they require a smaller human labour force.

The private environmental income generated by the dehesas has also seen to be highly important, given the fact that some owners show a willingness to accept a moderate level of profitability, with even negative margins, in exchange for being able to maintain a lifestyle, legacy existence values and other options of family leisure. Research involving environmental economic appraisal highlight the fact that the negative evolution of income provided by the commercial exploitation of dehesas is on occasions offset by the greater margin provided by self-consumption of private environmental services (Campos et al., 2009). Indeed, despite the fact that the main activity of dehesas is livestock farming, the private production generating the highest income can often involve the environmental services consumed by the owners themselves.

The present application of energy in modern dehesas comes in different ways: machinery, chemicals and technological knowledge are applied to the land. The higher productivity made possible by the addition of fossil fuel power has caused a number of shifts. Heavy ploughing cultivation may have contributed to soil degradation. Besides, the dehesas have become vulnerable to outside economic processes and have had to adapt quickly to such changes. Nowadays, the dehesa swings between solar-based systems and technified systems, depending on the energy imported and with an increasing dependence on food from outside sources but at a lower rate compared to more intensified livestock husbandry systems. It has been argued that the survival of the dehesa throughout the $20^{\text {th }}$ century was based on its adaptation to economic conditions (Martín Vicente and Fernández Alés, 2006); nevertheless, its survival should be linked to its inability to be transformed and changed to another more productive system.

One of its major problems, the lack of oak regeneration is partly the result of the less intensive human labour: farmers no longer have the time, the economical resources, or perhaps the know-how either, to take any care in the planting, guiding and protecting of the seedlings against animal browsing. The even-agedness of the oak stands in many dehesas is a weakness of the whole system if enough regeneration is not achieved (Díaz et al., 1997; Pulido et al., 2001). In fact, the regeneration challenge is inherent to the dehesa management because of the difficulties in combining grazing, cultivation, scrub clearing and oak regeneration.

Where abandonment occurs, the whole system may change. Forest or thicket recovery is beneficial for forest or shrubland-dwelling species, although it results in a habitat reduction for open habitat species. What will happen and what the trajectories of natural succession will be is not yet sufficiently known: there will probably be different scenarios depending on factors such as the degree of alteration and the vicinity to propagule sources.

From another point of view, thicket should not be considered as a "forbidden" element in the dehesas: it plays a role as a forage reserve for the livestock, reduces the risk of erosion on steep slopes and the regeneration of the oaks is enhanced by the presence of a certain degree of shrub cover.

Additionally, the climate change is likely to affect the dehesas (Eagleson and Segarra, 1985; Dale, 1997; Felicisimo, 2011). Currently, it is thought that the dehesas have started in some areas to show the consequences of climate change. In any case, there are thousands of hectares being affected by an oak decline disease, with evidence that a sound fraction of this decline is caused by a letal invasive species (Phytophthora cinnamomi) (Brasier, 1992; Sánchez et al., 2002, 2006).

The social and environmental impacts resulting from large-scale abandonment have not been explored in detail, but they are considerable. Counter-measures are being taken in terms of protecting the dehesas against their major threats related to the lack of economic and ecological sustainability through public investments and incentive programs based on the explicit or implicit recognition of the public services they provide. Although most livestock income depends on subsidies under European Union agriculture policies, it has been pointed out that there is a need for increasing the effective public support in order to contribute to maintaining the economic viability of the dehesa with its associated high biodiversity (Alagona et al., 2013). For instance, agri-enviromental regional aids have already been applied to dehesas in Spain by means of Regulations 2078/92, 1257/1999 and 1698/2005 (environment-friendly agricultural production methods and maintenance of the countryside). However, the application of EU agricultural and forestry aid schemes (direct payments and rural development) is problematic when applying to the dehesas, a multiple-use agrosystem characterised by extensive livestock grazing in forest land (according to national law definition of forest land in Law 43/2003, on Forestry), because EU regulations tend to distinguish rather sharply between agricultural and forestry subsidies.

In order to meet conservation demands in a changing social context, there is a need for updating the definition 
of the dehesa. The park-like dehesa, falling within an ecosystem- and landscape-based approach is not useful because it is not an administrative-oriented definition and it does not highlight the man-made productive character of the dehesa. In this sense, Andalusia Law 7/2010, referring to the dehesa, includes a definition based on a farming approach. According to this law, a dehesa is a farm mostly comprising a dehesa-type formation, subjected to a system of land use and management based principally upon extensive livestock farming and making use of pastures, fruits and browsing, as well as other forestry, hunting or agricultural uses, being a dehesatype formation a forestland occupied by a stratum of trees, with a tree cover percentage (area of land covered by the projection of the treetops) of between $5 \%$ and $75 \%$, mainly comprising holm oak, cork oak, gall oak or acebuche - wild olive (Olea europea, va. sylvetris), and occasionally other tree species, enabling the development of an essentially herbaceous stratum (pastures), for livestock or hunting species.

Therefore, this XXI century dehesa is a land-use system that shapes a specific landscape characterized by scattered trees and annual grasslands; it is an agrarian and forest enterprise managed on a farming rather than on a plot scale, meaning that a dehesa farm is often composed of a large proportion of park-like land combined with plots of crop lands, afforested pasture lands and dense thickets and woodlands; the key factor of this system is domestic livestock or, less frequently, game-hunting spe- cies such as deer; its income does not exclusively come from stock-raising; there may be agricultural and forestry yields such as cereals, cork or firewood.

\section{CONCLUSIONS}

The influence of rural history on the shape of the Mediterranean basin landscape has led to an extreme heterogeneity these days (Blondel and Aronson, 1999). In this heterogeneous environment, the importance of the historical, cultural and geographic dimension of ecology is often underestimated (di Castri, 1981). Centuries of pastoralism have brought considerable changes to the Mediterranean ecosystems. Sheep and goats are said to have had the most widespread impact on Mediterranean ecosystems through grazing and browsing (Seligman and Perevolotsky, 1994). The park-like dehesa is thought to be a good example of how human activities can be beneficial to many components of biological diversity (Pons and Quézel, 1985) and of how Mediterranean biodiversity depends on the conservation of the cultural landscape, assuming that the countryside's environmental, natural and social problems are related to each other (Phillips, 1988; Bennett, 1996).

Dehesa is a farming system coming from the past with the need of updating its management practices to provide enough tree regeneration to be sustainable in the long-term, reverting the decline of density and cover of oaks (Carruthers, 1993; Plieninger, 2007; Alagona et al., 2013).

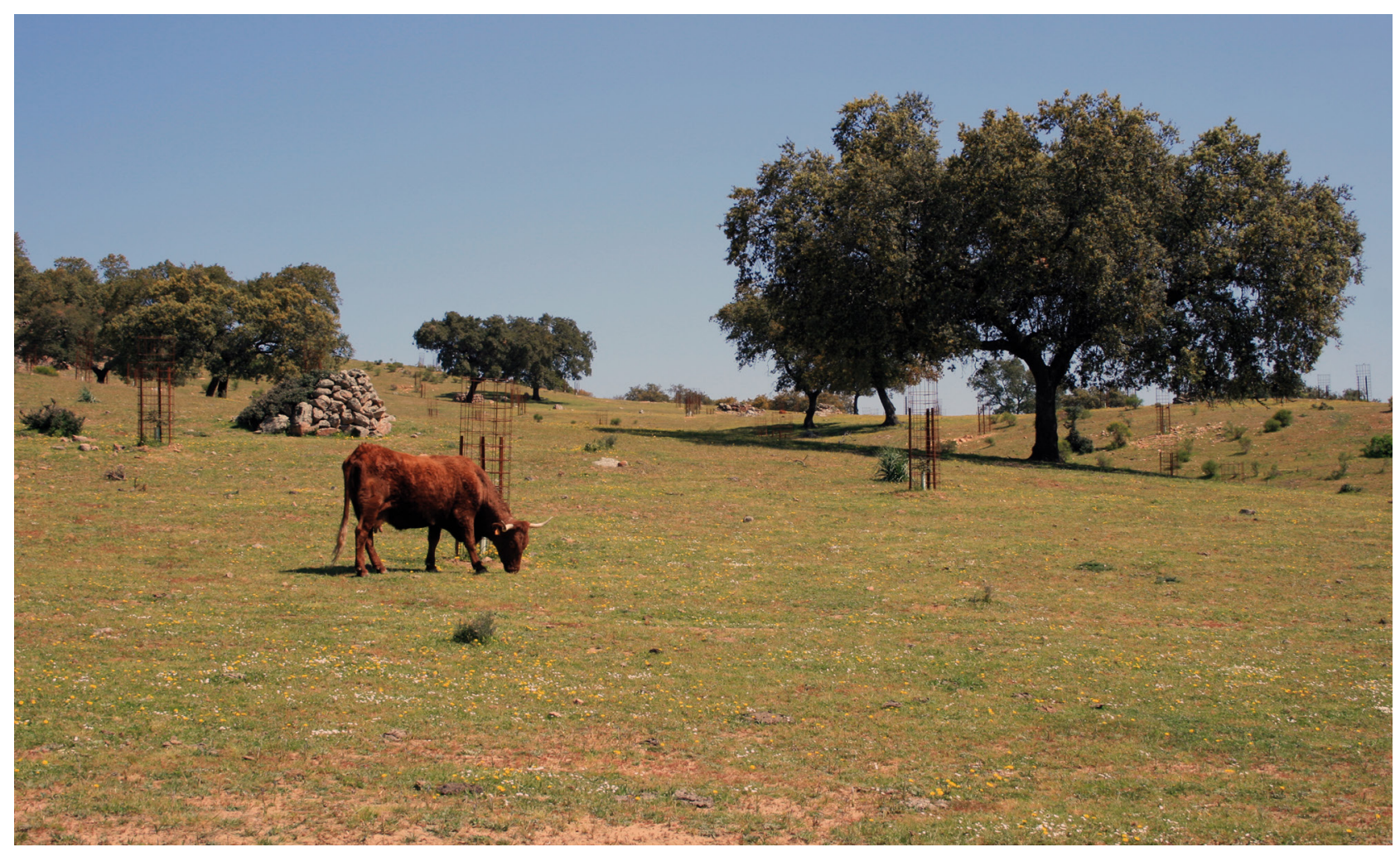

Рното 4. Management practices to provide enough tree regeneration in the dehesa. 
Although the changes of dehesas landscapes are reported to be explained by a complex set of social, economical, political, technological and natural drivers (Costa et al., 2014), responsible grazing remains in any case fundamental. Through over-grazing, tree renewal will be limited and aridization processes will increase; through under-grazing or grazing abandonment, dense woodland and shrubland ecosystems will develop, vanishing most of the socioeconomic and ecological values linked to the dehesa.

Well-managed dehesas are an outstanding model of agroforestry that provides economic incomes and ecosystem services (Lundgren, 1982; Rigueiro-Rodríguez et al., 2009; Marañón et al., 2012). The park-like dehesa is the result of a long historical record and we are being challenged to preserve this heritage. We may also participate in the evolution of this word through the design of the new dehesas. As shown above, in first instance there was a fenced pasture land. After that, a tree-layered pastureland mostly composed of the Quercus genus stands. Subsequently, there was a savannah-like landscape located in the southwestern Iberian Peninsula. Finally, a farm approach is emerging in order to recognize the essential link between socioproductive and ecological factors. Now is time to benefit from the dehesas approach: an integrated land-use system with grazing as the key management factor, useful for environmental care purposes and for increasing food quality.

At present, there is a wave of promoting agroforestry systems as a sustainable type of farmland (Herzog, 1998; Rigueiro-Rodríguez et al., 2009). The dehesa, with its set of economic products and non-commercial environmental services, could play an important role in the Mediterranean region. Adehesar, making dehesas, is one promising tool for managing Mediterranean lands (Parsons, 1962): the management of open forests through grazing would contribute to maintaining the overall biodiversity, fragmenting the landscape, generating rural amenities and reducing the risk of fire; it could also be an instrument for reducing the effect of the climate change on other types of vegetation as pine forests, abandoned olive or lentisk fields, which could be adehesados. However, for this purpose we need livestock and Mediterranean pastoralism, which, in fact, is an ecological and productive factor threatened with extinction.

\section{ACKNOWLEDGEMENTS}

The author wants to thank Dr. Javier Sanz for the invitation to write this paper, giving the opportunity (and the challenge) of conceptualizing the implications of updating ecological and historical concepts arising from the past. The text is indebted to the ideas, conversations and work carried out related to the dehesas in the Regional Ministry of Environment and Spatial Planning and the Regional Ministry of Agriculture, Fishing and Rural Development of Andalucia and in the framework of the Life Project BIODEHESA (Life 11/BIO/ES/000726) with many colleagues and Friends. I am indebt as well with Guillermo Ceballos Watling, who read carefully the text and made sound suggestions.

\section{NOTES}

1 Conclussion of Spanish Senate Report on Dehesa ecosystem conservation, November 2010.

2 Martín-Vicente and Fernández-Alés (2006) have quoted the personal diary of Fragoso de Sequeiros, a Portuguese member of the Enlightenment, who proposed the turning of the oak shrub land of the Alentejo, a region in the southwest of Portugal, into open oak parkland, in order to favour cultivation, in combination with animal husbandry, taking advantage of the acorns for nourishing pigs.

\section{REFERENCES}

Acosta Naranjo, Rufino (2002) Los entramados de la diversidad. Antropología social de la dehesa. Diputación de Badajoz, Badajoz.

Alagona, Peter S.; Linares, Antonio; Campos, Pablo and Huntsinger, Lynn (2013) "History and Recent Trends". In Mediterranean oak woodland working landscapes. Dehesas of Spain and ranchlands of California, edited by Campos, P.; Huntsinger, L.; Oviedo, J. L.; Starrs, P. F.; Díaz, M.; Standiford, R. B. and Montero, G. Springer, Dordrechjt: 25-59. doi: 10.1007/978-94007-6707-2_2.

Anes, Gonzalo (1994) El siglo de las Luces. Historia de España, IV. Alianza Editorial, Madrid.

Argente del Castillo Ocaña, Carmen (1991) La ganadería medieval andaluza, siglos XIII - XVI: reinos de Jaén y Córdoba. Diputación Provincial de Jaén, Jaén.

Aschmann, Homer (1973) "Man's impact on the several regions with Mediterranean Climates". In Mediterranean-Type Ecosystems. Origin and Structure, edited by di Castri, Francesco J. and Mooney, Harold A. Springer Verlag, New York: 363-367. doi: 10.1007/978-3-642-65520-3 21.

Bauer Manderscheid, Erich (1991) Los montes de España en la historia. Servicio de Publicaciones Agrarias, Ministerio de Agricultura, Pesca y Alimentación: Fundación Conde del Valle de Salazar, Madrid.

Bennett, G. (editor) (1996) Cultural landscapes. The conservation challenge in a changing Europe. Institute for European Environmental Policy, Arnhem and London.

Bignal, E. M. and Mc Cracken, D. I. (1996) "Low-intensity farming systems and the conservation of the country-side". Journal of Applied Ecology, 33: 413-424.

Blondel, Jaques and Aronson, James (1999) Biology and wildlife of the Mediterranean Region. Oxford University Press, Oxford.

Brasier, C. M. (1992) "Oak tree mortality in Iberia". Nature, 360: 539.

Braudel, Fernand (1975) The Mediterranean and the Mediterranean World in the Age of Philip II. Harper and Row, New York.

Cabo Alonso, A. (1998) "Formación histórica de las dehesas". In La dehesa. Aprovechamiento sostenible de los recursos naturales, coordinated by Hernández Díaz-Ambrona, Carlos G.. Editorial Agrícola, Madrid: 15-42

Calvo Poyato, José (1990) "Venta de baldíos y tensión social en Andalucía a mediados del siglo XVII". Agricultura y Sociedad, 33: 95-124.

Campos, Pablo (1983) "La degradación de los recursos naturales de la dehesa. Análisis de un modelo de dehesa tradicional". Agricultura y Sociedad, 26: 289-381.

Campos, Pablo (1984) Economía y ecología en la dehesa extreme$\tilde{n} a$. Instituto de Estudios Agrarios, Pesqueros y Agroalimentarios, Madrid.

Campos, Pablo; Cañellas, Isabel and Montero, Gregorio (2003) "Evolución y situación actual del monte adehesado". In La gestión forestal de las dehesas, edited by Pulido, F. J.; Campos, P. and Montero, G. Instituto del Corcho, la Madera y el Carbón, Badajoz: 27-37.

Campos, P; Oviedo, J. L.; Caparrós, A.; Huntsinger, L. and Seita Coelho, I. (2009) "Contingent valuation of woodland owner private amenities in Spain, Portugal, and California”. Rangeland Ecology and Management, 62: 240-252. 
Campos, P.; Huntsinger, L.; Oviedo, J. L.; Starrs, P. F.; Díaz, M.; Standiford, R. B. and Montero, G. (2013) Mediterranean oak woodland working landscapes. Dehesas of Spain and ranchlands of California. Springer, Dordrecht.

Cano García, Gabriel (1990) Baza, 1752, según las Respuestas Generales del Catastro de Ensenada. Editorial Tabapress, Madrid.

Carruthers, S. P. (1993) "The dehesa of Spain - exemplars or anachronims?". Agroforestry Forum, 4: 43-52.

Casa de Velázquez (1986) Supervivencia de la Sierra Norte. Ministerio de Agricultura, Pesca y Alimentación, Madrid.

Cerdá, A.; Schabel, S.; Ceballos, A. and Gómez, D. (1988) "Soil hydrological response under simulated rainfall in the dehesa land system (Extremadura, SW Spain) under drought conditions". Earth Surface Processes and Landforms, 23: 195-209.

Ceresuela, José Luis (1998) "De la dehesa al bosque mediterráneo". In La dehesa. Aprovechamiento sostenible de los recursos naturales, edited by Hernández Díaz-Ambrona, Carlos G. Editorial Agrícola, Madrid: 45-52.

Clemente Ramos, Julián (2000) "La evolución del medio natural en Extremadura (c. 1142- c. 1525)" In El medio natural en la España medieval. Actas del I Congreso sobre Ecohistoria e Historia Medieval, Cáceres: 21.

Clemente Ramos, Julián (2005) "La organización del terrazgo agropecuario en Extremadura (siglos XV-XVI)". En la España Medieval, 28: 49-80.

Corominas, Joan (1997) Breve diccionario etimológico de la lengua castellana. Editorial Gredos, Madrid.

Costa, Joaquín (1898) Colectivismo agrario en España. Editorial Guara, Zaragoza.

Costa, A.; Madeira, M.; Lima-Santos, J. and Plieninger, T. (2014) "Recent dynamics of evergreen oak-wood pastures in southwestern Iberia". In European wood-pastures in transition. A social-ecological approach, edited by Hartel, Tibor and Plieninger, Tobias. Routledge, New York: 70-82.

Dale, V. H. (1997) "The relationship between land-use change and climate change". Ecological Applications, 7: 753-769.

Dawson, T. and Fry, F. (1998) "Agriculture in nature's image". Trends in Ecology and Evolution, 13: 50-51.

Di Castri, Francesco (1981) "Mediterranean-type shrublands of the world". In Ecosystems of the World II. Mediterranean-type Shrublands, edited by di Castri, F.; Goodall, D. W. and Specht, R. L. Elsevier Scientific Publishing Company, Amsterdam: $1-45$.

Díaz, Mario; Campos, Pablo and Pulido, Fernando (1997) "The Spanish dehesa: a diversity in land-use and wildlife". In Farming and birds in Europe, edited by Pain, Deborah J. and Pienkowski, M. W. Academic Press, London: 179-206.

Domínguez Ortiz, Antonio (1963) La sociedad española en el siglo XVII. Consejo Superior de Investigaciones Científicas, Madrid.

Domínguez Ortiz, Antonio (1976) Sociedad y Estado en el siglo XVIII. Editorial Ariel, Barcelona.

Eagleson, P. S. and Segarra, R. I. (1985) "Water limited equilibrium of savanna vegetation systems". Water Resources Research, 21: 1483-1493.

Felicísimo, Ángel M.; Muñoz, Jesús; Villalba, Carlos Javier and Mateo, Rubén G. (2011) Impactos, vulnerabilidad y adaptación al cambio climático de la biodiversidad española. 1. Flora y vegetación. Oficina Española de Cambio Climático, Ministerio de Medio Ambiente y Medio Rural y Marino, Madrid.

Fernández-Alés, R.; Martín, A.; Ortega, F. and Ales, E. (1992) "Recent changes in landscape structure and function in a mediterranean region of SW Spain (1950-1984)". Landscape Ecology, 7: 3-18.

Ferrer, C.; San Miguel, A. and Olea, L. (2001) "Nomenclator básico de pastos en España”. Pastos, 31: 7-44.

García Sanz, Ángel (1998) "Los privilegios mesteños en el tiempo, 1273-1836: una revisión de la obra de Julius Klein”. In Mesta, trashumancia y lana en la España Moderna, edited by Ruiz Martín, Felipe and García Sanz, Ángel. Editorial Crítica, Barcelona: 65-89.
González-Bernáldez, Fernando (1991) "Ecological consequences of the abandonment of traditional land use systems". In Land abandonment. Options Mediterranéenes, edited by Baudry, J. and Bunce, R.G.H. Centre International de Hautes Etudes Agronomiques Mediterraneenes, Paris: 53-61.

Grove, A. T. and Rackham, O. (2001) The nature of Mediterranean Europe: an ecological history. Yale University Press, New Haven and London.

Guzmán Álvarez, José Ramón (2004) El palimpsesto cultivado. Historia de los paisajes del olivar andaluz. Consejería de Agricultura y Pesca, Sevilla.

Hernández Díaz-Ambrona, Carlos G. (1995) "La dehesa extremeña”. Agricultura, 750: 37-41.

Herr, Richard (1989) Rural change and royal finances in Spain at the end of the old regime. University of California Press, California.

Herzog, F. (1998) "Streuobst: a traditional agroforestry system as a model for agroforestry development in temperate Europe". Agroforestry Systems, 42: 61-80.

Huntsinger, Lynn; Campos, Pablo; Starrs, Paul F.; Oviedo, José L. and Díaz, Mario (2013) "Working landscapes of the Spanish Dehesa and the California oak woodlands: an introduction". In Mediterranean oak woodland working landscapes. Dehesas of Spain and ranchlands of California, edited by Pablo Campos, Lynn Huntsinger, Jose Luis Oviedo Pro, Paul F Starrs, Mario Diaz, Richard B Standiford, Gregorio Montero. Springer, Dordrecht: 3-24. doi: 10.1007/978-94-007-6707-2 1.

Joffre, R. and Rambal, S. (1988) "Soil water improvement by trees in the rangelands of southern Spain". Oecologia Plantarum, 9: 405-422.

Joffre, R.; Vacher, J.; De Los Llanos, C. and Long, G. (1988) "The dehesa: an agrosilvopastoral system of the Mediterranean region with special reference to the Sierra Morena area of Spain". Agroforestry System, 6: 71-96.

Joffre, R. and Rambal, S. (1993) "How tree cover influences the water balance of Mediterranean rangelands". Ecology, 74: 570582.

Joffre, R.; Rambal, S. and Ratte, J. P. (1999) "The dehesa system of southern Spain and Portugal as a natural ecosystem mimic". Agroforestry System, 45: 57-79.

Jordana y Morera, José (1900) Algunas voces forestales. Ministerio de Agricultura, Pesca y Alimentación, Madrid.

Klein, Julius (1920) The Mesta: a study in Spanish economy history 1273-1836. Cambridge University Press, Cambridge.

Kondo, Agustín Y. (1990) La agricultura española del siglo XIX. Ministerio de Agricultura, Pesca y Alimentación - Editorial Nerea, Madrid.

Lavado Contador, J.F.; Schnabel, S. and Trenado Ordóñez, R. (2000) "La dehesa. Estado actual de la cuestión". Clio: History and History Teaching, 17, http://clio.rediris.es/geografia/dehesa.htm, [consulted 3/March/2016].

Linares-Luján, Antonio M. and Zapata Blanco, Santiago (2003) "Una visión panorámica de ocho siglos". In La gestión forestal de las dehesas, edited by Pulido, Fernando J.; Campos Palacín, Pablo and Montero González, Gregorio. Instituto del Corcho, la Madera y el Carbón, Badajoz: 13-25.

Linares, Antonio (2012) "La evolución de la dehesa: entre la persistencia y el cambio". In Santiago Zapata Blanco: Economía e Historia Económica, edited by Linares, Antonio M.; Llopis, Enrique and Pedraja, Francisco. Fundación Caja de Extremadura, Cáceres: 11-35.

López Sáez, José Antonio; López García, Pilar; López Merino, Lourdes; Cerrillo Cuenca, Enrique; González Cordero, Antonio and Prada Gallardo, Alicia (2007) "Origen prehistórico de la dehesa en Extremadura: Una perspectiva paleoambiental”. Revista de Estudios Extremeños, 63: 493-509.

Lundgren, B. (1982) "What is Agroforestry?". Agroforestry Systems, 1: 7-12.

Lynch, John (1964) Spain under the Habsburgs. Oxfod United Press, New York.

Mangas Navas, José Manuel (1982) El régimen comunal agrario de los Consejos de Castilla. Ministerio de Agricultura, Madrid. 
Marañón, Teodoro (1986) "Plant species richness and canopy effect in the savanna-like dehesa of SW Spain". Ecologia Mediterranea, 12: 131-141.

Marañón, Teodoro; Ibáñez Moreno, Beatriz; Anaya Romero, María and Muñoz Rojas, M. (2012) "Estado y tendencia de los servicios de los ecosistemas forestales de Andalucía". In Evaluación de Ecosistemas del Milenio en Andalucía. Consejería de Medio Ambiente, Junta de Andalucía, Sevilla. http://hdl.handle. net/10261/72607.

Marañón, Teodoro; Ibáñez Moreno, Beatríz; Anaya-Romero, María; Muñoz-Rojas, M. and Pérez-Ramos, Ignacio Manuel (2012) "Oak trees and woodlands providing ecosystem services in Southern Spain". In Trees beyond the wood conference proceedings, September 2012, edited by Rotherham, Ian D.; Handley, Christine; Agnoletti, Mauro and Samojlik, Tomasz. Wildtrack Publishing, Sheffield: 369-378.

Martín-Vicente, A. and Fernández-Alés, R. (2006) Long term persistence of dehesas. Evidence from history. Agroforestry Systems, 67: 19-28.

Moral, A. del (1979) La agricultura española a mediados del siglo $X I X$. Resultados de una encuesta agraria de la época. Ministerio de Agricultura, Madrid.

Moreno, Gerardo and Pulido, Fernando J. (2009) "The functioning, management and persistence of dehesas". In Agroforestry in Europe: current status and future prospects, edited by Rigueiro-Rodríguez, A.; McAdam, J. and Mosquera-Losada, M. R. Springer Science: 127-160.

Naredo, José Manuel and Campos, Pablo (1980) "Los balances energéticos en la agricultura española". Agricultura y Sociedad, 15: 163-256.

Naredo, José Manuel (1996) La evolución de la agricultura en España (1940-1990). Universidad de Granada, Granada.

Parsons, J. D. (1962) "The Acorn-Hog Economy of the Oak Woodlands of Southwestern Spain". The Geographical Review, 2: 211-235.

Payne, Stanley G. (1973) A History of Spain and Portugal. University of Wisconsin Press, Wisconsin.

Perdices Blas, Luis (1993) Pablo de Olavide (1725-1803) el Ilustrado. Editorial Complutense, Madrid.

Phillips, A. (1988) "The nature of cultural landscapes". Landscape Research, 23: 21-38.

Plieninger, T. and Wilbrand, C. (2001) "Land use, biodiversity conservation and rural development in the dehesas of Cuatro Lugares, Spain". Agroforestry Systems, 51: 23-34.

Plieninger, T.; Pulido, F. and Konold, W. (2003) "Effects of landuse history on size structure of holm oak stands in Spanish dehesas: implications for conservation and restoration". Environmental Conservation, 30: 61-70.

Plieninger, T.; Pulido, F.J.and Schaich, H. (2004) "Effects of landuse and landscape structure on holm oak recruitment and regeneration at farm level in Quercus ilex dehesas". Journal of Arid Environment, 57: 345-364

Plieninger, T. (2007) "Compatiblity of livestock grazing with stand regeneration in Mediterranean holm oak parklands". Journal for Nature Conservation, 15: 1-9.

Pons, A. and Quézel, P. (1985) "The history of flora and vegetation and past and present human disturbance in the Mediterranean region". In Plant conservation in the Mediterranean area, edited by Gómez Campo, C. Dr. W. Junk, Dordrecht: 25-43.

Puerto, A. and Rico, M. (1988) "Influence of tree canopy (Quercus rotundifolia Lam. and Q. Pyrenaica Willd.) on old-field succession in marginal areas of Central-Western Spain". Acta Oecologica. Oecologia Plantarum, 9: 337-358.

Pulido, F. J.; Díaz, M.and Hidalgo de Trucios, S. (2001) "Size structure and regeneration of Spanish holm oak Quercus ilex forests and dehesas: effects of agroforestry use on their long-term sustainability". Forest Ecology and Management, 146: 1-13.

Pulido, Fernando J.; Campos, Pablo and Montero, Gregorio (2003) La gestión forestal de las dehesas. Historia, ecología, selvicultura y economía. Instituto del Corcho, la Madera y el Carbón, Junta de Extremadura, Mérida.
Pulido, Fernando J. and Picardo, Alvaro (coord.) (2010) Libro Verde de la dehesa. Documento para el debate hacia una Estrategia Ibérica de gestión. Junta de Castilla y León, Sociedad Española de Ciencias Forestales, Sociedad Española para el Estudio de los Pastos, Asociación Española de Ecología Terrestre y Sociedad Española de Ornitología. http://www.researchgate.net/publication/229812274 Libro Verde de la Dehesa

Rigueiro-Rodríguez, A.; McĀ̄am, J. and Mosquera-Losada, M. R. (2009) Agroforestry in Europe: current status and future prospects. Springer Science

Rodríguez-Estévez, V.; Sánchez-Rodríguez, M.; Arce, C.; García, A. R.; Perea, J.M. and Gómez-Castro, A.G. (2012) "Consumption of Acorns by Finishing Iberian Pigs and Their Function in the Conservation of the Dehesa Agroecosystem". In Agroforestry for biodiversity and ecosystem services. Science and practice, edited by Leckson Kaonga, M. InTech, Rijeka: 1-22.

Salomon, N. (1964) La campagne de Nouvelle Castile a la fin du хvле siècle d'aprés les relations topographiques. École Practique des Hautes Etudes, París.

Sánchez, M. E.; Caetano, P.; Ferraz, J. and Trapero, A. (2002) "Phytophthora disease of Quercus ilex in Southwestern Spain". Forest Pathology, 32: 5-18.

Sánchez, M. E.; Caetano, P.; Romero, M. A.; Navarro, R. M. and Trapero, A. (2006) "Phytophthora root rot as the main factor of oak decline in southern Spain". In Progress in research on Phytophthora diseases of forests trees, edited by Brasier, C.; Jung, T. and Obwald, W. Forest Research, Farnham: 149-154.

Sánchez Salazar, Felipa (1988) Extensión de cultivos en España en el siglo XVII. Ministerio de Agricultura, Pesca y Alimentación Siglo XxI, Madrid.

San Miguel, Alfonso (1994) La dehesa española. Escuela Técnica Superior de Ingenieros de Montes, Madrid.

Scarascia-Mugnozza, G.; Oswald, H.; Piussi, P. and Radoglou, K. (2000) "Forests of the Mediterranean region: gaps in knowledge and research needs". Forest Ecology and Management, 132: 97-109.

Scholes, R. J. and Archer, S. R. (1997) "Tree-grass interactions in savannahs". Annual Review of Ecology and Systematics, 28: $517-544$.

Seligman, N. G. and Perevolotsky, A. (1994) "Has intensive grazing by domestic livestock degraded Mediterranean Basin rangelands?" In Plant-animal interactions in the Mediterranean-type Ecosystems, edited by Arianoutsou, M. and Groves, R.H. Elsevier: 93-103.

Silva Pérez, R. (2010) "La dehesa vista como paisaje cultural. Fisionomías, funcionalidades y dinámicas históricas”. Ería, 82: $143-157$.

Simmons, Ian G. (1989) Changing the face of the Earth. Blackwell Publishers, Oxford.

Simpson, James (1996) Spanish agriculture. The long Siesta, 17651965. Cambridge University Press, UK.

Standiford, R. B.; Ovando, P.; Campos, P. and Montero, G. (2013) "Models of oak woodland silvopastoral management". In Mediterranean oak woodland working landscapes. Dehesas of Spain and ranchlands of California, edited by Campos, P.; Huntsinger, L.; Oviedo, J. L.; Starrs, P. F.; Díaz, M.; Standiford, R. B. and Montero, G. Springer, Dordrechjt: 245-272.

Stevenson, A.C. and Harrison, R. J. (1992) "Ancient forests in Spain: a model for land-use and dry forest management in South-west Spain from 4000 BC to 1900 AD". Proceedings of the Prehistoric Society, 58: 227-247.

Stevenson, A. C. (1985) "Studies in the vegetational history of S.W. Spain. I. Modern pollen rain in the Doñana National Park, Huelva". Journal of Biogeography, 12: 243-268.

Stevenson, A. C. and Moore, P. D. (1988) "Studies in the vegetational history of S.W. Spain. IV. Palynological investigations at El Acebrón, Huelva". Journal of Biogeography, 15: 339-361.

Torres Márquez, P. (1994) Hinojosa del Duque en el S. XVIII. Diputación Provincial de Córdoba, Córdoba.

Vacher, J. (1984) Analyse phyto- et agro-écologique des dehesas pastorales de la Sierra Norte. CNRS-CEPE, Montpellier. 
The image of a tamed landscape: dehesa through History in Spain $\bullet 17$

Vacher, J.; Joffre, R.; Ortega, F.; Fernández-Alés, R. and Martín Vicente, A. (1985) "L'organisation de l'espace dans la Sierra Norte de Sévile (Sierra Morena) et les problèmes actuels des dehesas". Revue Géographique des Pyrénées et du Sud-Ouest, 56: 179-201.

Vassberg, David E. (1974) "The tierras baldías: community property and public lands in 16th century Castile". Agricultural History, 48: 393-401.
Vassberg, David E. (1975) "The sale of tierras baldias in sixteenth century Castile". Journal of Modern History, 47: 629-654.

Vassberg, David E. (1984) Land and Society in Golden Age Castile. Cambridge University Press.

Zambrana, Juan Francisco (1987) Crisis y modernización del olivar. Ministerio de Agricultura, Madrid. 